\title{
非線形渦粘性モデルを用いた LES/RANS ハイブリッド乱流伝熱モデル A hybrid LES/RANS approach using anisotropy-resolving algebraic turbulence models for predicting turbulent scalar transfer
}

\author{
O学 犬束 稔 (九大院) \\ 正 安倍 賢一（九大工） \\ Minoru INUZUKA and Ken-ichi ABE, Dept. of Aero. \& Astro., Kyushu University, Fukuoka, 812-8581
}

\begin{abstract}
In order to derive a possible path for developing a large eddy simulation (LES) applicable to high Reynolds-number turbulent flow, a hybrid approach connecting LES with the Reynolds-averaged Navier-Stokes (RANS) modeling in the near wall region is studied. In contrast to most of the previous studies, an advanced non-linear eddy-viscosity model and a higher order extension of the generalized gradient diffusion hypothesis model are introduced to resolve near-wall turbulence and turbulent scalar transfer more correctly. The proposed model is applied to fully-developed channel flow with various grid resolution. The present model provides encouraging results for developing this kind of hybrid LES/RANS model.
\end{abstract}

Key Words: Turbulence, Turbulent Scalar Transfer, Hybrid LES/RANS Model, Non-linear Eddy-Viscosity Model

\section{1。緒言}

ラージ・エディ・シミュレーション(LES)は, 計算機の 発達に伴い, 複雑乱流場の予測への適用が可能になり, 乱 流計算の主力になりつつある。しかしながら，高レイノル ズ数 $(R e)$ 乱流にLESを適用する場合, 現在なお解決す心゙き 問題が残されており, 高Re乱流における壁面近傍の取り扱 いの問題は深刻である.なぜならば，壁面近傍の流れを解 像するには非常に多くの計算格子が必要だからである．例 えば，滑りなし条件を適用してチャネル乱流を計算する場 合, 適切なLESを行う為に必要とされる壁面近傍の格子解 像度は，壁座標表示で概ね $\Delta x^{+} \sim 100$ ( $x$ :流れ方向), $\Delta z^{+} \sim$ 20 (z:スパン方向)程度とされている.これをRe $e_{t}\left(=u_{t} H /\right.$ $v)=10^{4}$ (バルク $R e$ で約 $5 \times 10^{5}, H:$ チャネル半幅, $u_{\tau}$ :摩擦速 度)のチャネル乱流に適用すると, スパン方向にチャネル半 幅当たり 500 点の格子点数が必要となり, 工学的な観点か ら考えるとこれは受け入れ難い要求である.

この問題を解決すべく多くの研究グループが, 高Re乱流 おける壁面近傍の計算コスト削減に向けた努力を行ってき た. 中でも，壁面近傍でレイノルズ平均ナビェ・ストーク ス(RANS) モデルを適用し，中心領域でLESを用いる “LES/RANSハイブリッド手法”が注目されている。これ までの研究 ${ }^{(1) \sim(3)}$ により, LES/RANSハイブリッド手法の有 用性は確認されているが, 従来の研究では殆どの場合 RANSとして線形モデルが採用されており，壁面近傍での 乱れの非等方性まで立ち入った議論がなされていない，し かし，ハイブリッド手法では常に壁面近傍でRANSが採用 されることを考えると，この問題は重要である。例えば乱 流伝熱予測において，最近の代数型熱流束モデル(4)(5)では 乱れの非等方性の適切な再現を前提としており，壁面近傍 で線形のRANSモデルは採用できない，そこで，壁面での 乱れの非等方性を正しく表現できる非線形のRANSモデル

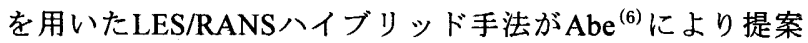
され, 様々な格子解像度のチャネル流れで適切な予測が得 られた.

本研究では, より高精度な乱流伝熱予測を行う為に, 速

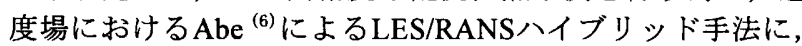
GGDHの高次展開型モデル ${ }^{(4)}(5)$ を組み合わせた手法を検討 する.このハイブリッドモデルを種々の格子解像度のチャ ネル乱流に適用し，乱流伝熱を含めた予測精度に関する議 論を行う。

\section{2. 計算手法及び計算条件}

フィルター平均(またはレイノルズ平均)された強制対流 スカラ一輸送に対する支配方程式は以下のようになる.

$$
\frac{D \bar{T}}{D t}=\frac{\partial}{\partial x_{i}}\left(\frac{v}{\operatorname{Pr}} \frac{\partial \bar{T}}{\partial x_{i}}-q_{i}\right)
$$

ここで, ( RANS領域ではレイノルズ平均された值を示す. 式(1)にお いて, $\bar{T}, v, \operatorname{Pr}$ はそれぞれGS (平均) スカラー, 動粘性係数, プラントル数を表す. LESとRANSの接続に関しては, Abe ${ }^{(6)}$ のハイブリッド手法に従い, レイノルズ応力 $\tau_{i j}$ と同 様に乱流熱流束 $q_{i}$ を以下の式で定義する.

$$
\begin{gathered}
\tau_{i j}=\left(1-f_{h b}\right){\overline{u_{i} u_{j}}}_{(R A N S)}+f_{h b} \tau_{i j}(L E S) \\
q_{i}=\left(1-f_{h b}\right){\overline{u_{i} t}}_{(R A N S)}+f_{h b} q_{i(L E S)}
\end{gathered}
$$

$f_{h b}$ はLESとRANSを滑らかに接続するための関数である. $f_{h b}$ は，LESが採用される壁から離れた領域では 1 となり，壁 から離れた領域では 0 となる， $f_{h b}$ は次の式で表される ${ }^{(6)}$.

$$
f_{h b}=1-\exp \left\{-\left(\frac{n}{C_{h b} \Delta}\right)^{6}\right\}, \Delta=\sqrt{\frac{\Delta_{x} \Delta_{y} \Delta_{z}}{\min \left(\Delta_{x}, \Delta_{y}, \Delta_{z}\right)}}, C_{h b}=4.0
$$

RANS領域において，レイノルズ応力のモデル化に関し ては, Abe ${ }^{(6)}$ のハイブリッド手法に従いAbe et al. ${ }^{(7)}$ のデ ルを採用した。 また乱流熱流束は, GGDHの高次展開型モ デル (4) (5)を用いてモデル化を行った. LES領域のレイノル ズ応力及び乱流熱流束は, RANSと同様の表式を用いてモ デル化を行っている．なおLES領域の乱れエネルギー $k_{s}$ は， 以下のフィルタリングに基づくモデルを採用した ${ }^{(6)}$.

$$
k_{s}=C_{k} \frac{1}{2}\left(\bar{U}_{i}-\hat{\bar{U}}_{i}\right)^{2}, C_{k}=4.5
$$

本研究では本ハイブリッドモデルの基本性能を確認する ために, $R e_{\tau}=640$ のヂャネル流れで計算を行った. 格子点 数は $31(x) \times 61(y) \times 31(z)$ とし, 計算領域を $6 H \times 2 H \times 1.5 H$, $12 H \times 2 H \times 3 H, 24 H \times 2 H \times 6 H$ と変化させることで, 3 通り の格子解像度 $(\Delta=0.1,0.2,0.4)$ について計算を行った. また， 何れの場合でも壁面垂直方向の格子解像度は $y_{w}{ }^{+} \leqq 1$ を確 保している. スカラー場についてはPr=0.71 とし, DNS ${ }^{(8)(9)}$ と同じ境界条件を用いた。本計算は, Lien and Leschziner ${ }^{(10)}$ によって開発されたSTREAMコードを用いた。 


\section{3、計算結果及び考察}

$R e_{\tau}=640$ の計算結果をDNSデータ ${ }^{(8)}{ }^{(9)}$ と比較して示す. Fig.1より, 平均速度分布は何れの格子解像度においても, DNS とほぼ一致しLESとRANSが滑らかに接続されている ことがわかる. Fig.2より，レイノルズせん断応力において も Resolved Stress(RS) と Modeled Stress(MS)を足したTotal Stress(TS)がDNSと何れの格子解像度でも概ね一致してい る. また $\Delta=0.4$ の場合は, RSがほぼ 0 となりRANSのみの 計算結果に近く, 本ハイブリッドモデルはより格子が粗い 場合でもRANSの予測精度を保障することがわかる. Fig.3 はレイノルズ垂直応力分布を比較したものであるが，DNS とほぼ一致し乱れの非等方性がよく再現されている. しか し, $\Delta=0.1$ では接続領域付近で再分配の抑制が生じており, TSがDNSよりも非等方性が強くなっている.また， $\Delta=0.2$ ではLES領域全体で再分配の抑制傾向が見られる.

Fig.4〜6よりスカラー分布に関しても, 何れの格子解像 度においてもLESとRANSが滑らかに接続されている. 平均 スカラー分布では, $\Delta=0.2$ でやや上方にずれが見られるが, 概ねDNSと一致しており，ヌッセルト数も適切に予測して いることがわかる. Fig.6 の主流方向の乱流スカラ一流束に ついては, $\Delta=0.1$ で壁面垂直方向の乱流スカラー流束のRS が最大付近で, $\Delta=0.2$ ではLES領域全体で過大予測された. これはFig.3で見られた傾向と一致し, $t$ が $u$ と相関が強い(11) 為であると考えられる。

\section{4。まとめ}

壁面乱流及び乱流スカラー輸送をより高精度に予測する 為に, NLEVM 及び GGDH の高次展開型モデルを用い，そ の有効性を確認した．平均スカラー分布と壁垂直方向熱流 束については良い結果が得られたが, 乱れの再分配の抑制 に伴い, 壁面垂直方向の乱流スカラー流束は LES 領域で過 大予測された。 今後, 更なる LES/RANS ハイブリッドモデ ルの発展の為に, 様々な流れ場に適用すると同時に, 妥当 性の検証・改良を進めることが重要である.

\section{4. 謝辞}

本研究の一部は, 平成 16 年度科学研究費補助金 (No. 15360450, No. 15106013)の支援を頂きました.ここに 記して梁く感謝の意を表します。

\section{参考文献}

(1) Nikitin,N.V., Nicoud,F., Wasistho,B., Squires,K.D. and Spalart, P.R.: Phys. Fluids, 12 (2000) 1629-1632.

(2)Hamba,F.:Theoret.Comput.Fluid Dynamics,16(2003)387-403

(3) Davidson, L., and Peng ,S.H.: Int. J. Numer. Meth. Fluids, 43 (2003) 1003-1018.

(4) Suga,K., and Abe,K.:Int.J.Heat Fluid Flow, 21(2000) 37-48.

(5) Abe,K., and Suga,K.:Int.J.Heat Fluid Flow, 22(2001) 19-29.

(6) Abe,K.: Int. J. Heat Fluid Flow, 26 (2005) 204-222.

(7) Abe,K., Jang,Y., and Leschziner,M.A.:Int. J. Heat Fluid Flow, 24 (2003) 181-198.

(8) Abe,H., Kawamura,H. and Matsuo,Y.: ASME J. Fluids Eng., 123 (2001) 382-393.

(9) Abe,H., Kawamura,H.: Proc. of 9th European Turbulence Conference, 399-402, 2002.

(10) Lien,F.S., and Leschziner,M.A.: Comput. Methods Appl. Mesh. Engrg, 114 (1994) 123-148.

(11) Moser,R.D., Kim,J., and Mansour,N.N.: Phys. Fluids, 11 (1999) 943-945.

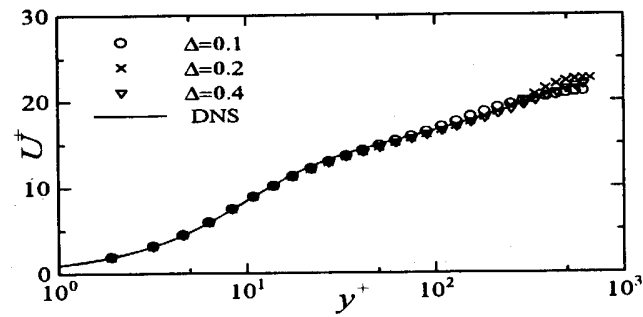

Fig.1 : Mean velocity profiles

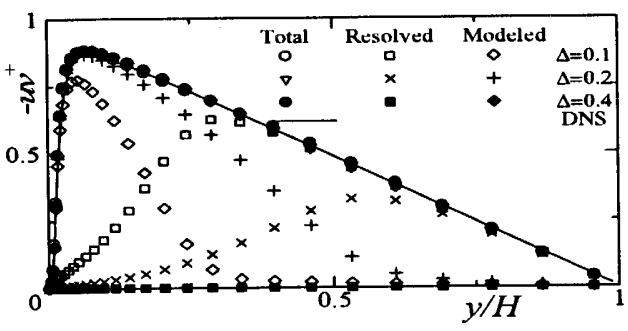

Fig.2 : Reynolds shear stress

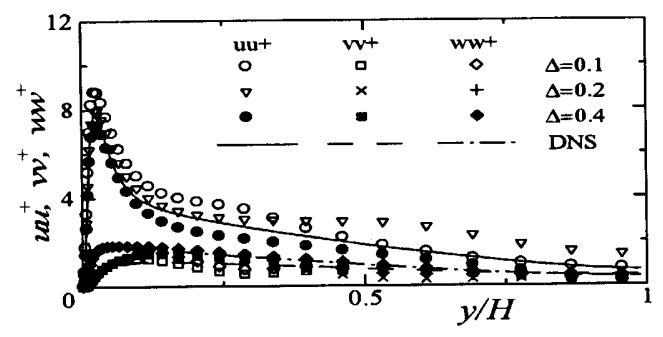

Fig.3 : Reynolds normal stresses

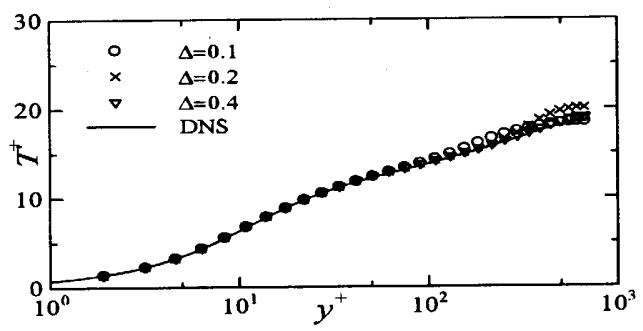

Fig. 4 : Mean scalar profiles

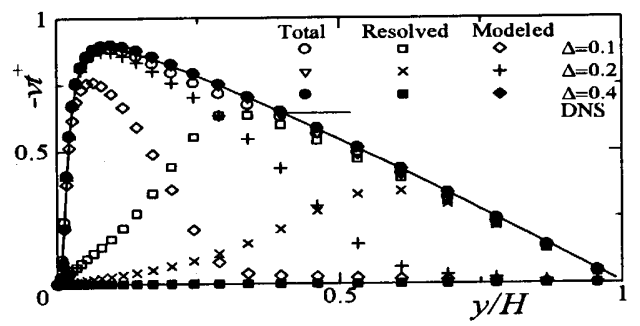

Fig.5 : Wall-normal scalar flux

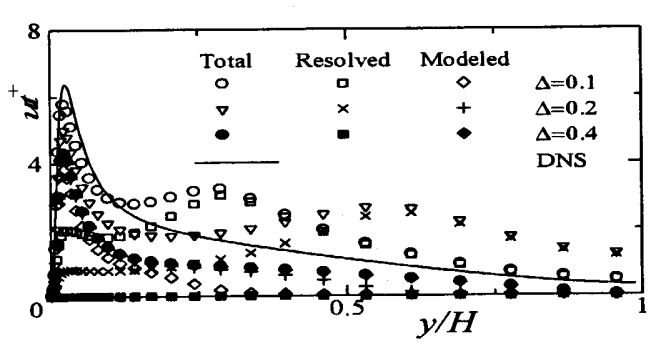

Fig.6 : Streamwise scalar flux 